\title{
Middle Eastern
}

National Cancer Institute

\section{Source}

National Cancer Institute. Middle Eastern. NCI Thesaurus. Code C77820.

Denotes a person having origins in the region of southwest Asia, between the India subcontinent and Europe, including Kuwait, Turkey, Lebanon, Israel, Iraq, Iran, Jordan, Saudi Arabia, lands east of Pakistan or the other countries of the Arabian Peninsula. Also includes people of Jewish ethnicity including Sephardic and Ashkenazic. 